\title{
The Potential of Multi-Species Mixtures to Diversify Cover Crop Benefits
}

\author{
Tejendra Chapagain *, Elizabeth A. Lee and Manish N. Raizada \\ Department of Plant Agriculture, University of Guelph, Guelph, Ontario N1G 2W1, Canada; \\ lizlee@uoguelph.ca (E.A.L.); raizada@uoguelph.ca (M.N.R.) \\ * Correspondence: tejendra@uoguelph.ca
}

Received: 22 January 2020; Accepted: 3 March 2020; Published: 7 March 2020

\begin{abstract}
Cover crops provide a range of well-documented benefits to growers and the environment. However, no single species can deliver all of these benefits, and hence planting mixtures is gaining increasing attention. To the best of our knowledge, there is no comprehensive review on different multi-mix strategies. This article reviews available studies on multi-mixes, focusing on temperate North America, and discusses objective criteria for selecting components of a multi-mix and what future research is needed. Very few peer-reviewed studies on multi-mixes are currently available; a diversity of species compositions is being tested with a wide range of potential benefits but also with various limitations. Selection of species in multi-mixes is based on different criteria that help improve multiple ecosystem services. An emerging concept is the importance of selecting cover crop species with functional complementarity rather than simply increasing the number of species. Based on this concept, objective criteria have been developed to select the species for a multi-mix: grower objectives/primary purpose of planting the cover crop, crop rotation and cropping system compatibility, above and belowground compatibility, complementarity of different ecosystem functions, compatibility with the growing environment, duration for cover crop growth, termination option(s) available, input/labour costs, planting equipment required, persistence/weediness, and potential net economic returns. We propose a step-wise procedure to develop effective multi-species mixtures. The number of species and their ratio in the mixtures will depend on objective criteria, and hence long-term research is required to assess different species compositions and their impacts.
\end{abstract}

Keywords: cover crop; sole cover; multi-species mix; crop rotation; cropping system; complementary mixture; ecosystem functions; soil health

\section{Introduction}

Cover crops are considered an important agroecological strategy for field crop production and soil fertility management. Cover crops are any crops that are planted between periods of normal crop production with an objective of enhancing multiple ecosystem services [1,2]. A cover crop can function as a green manure when it is plowed under and incorporated into the soil while still green or at maturity [3]. Cover crops increase plant residues retained on the soil surface [4-6], minimize soil disturbance and erosion [7-9], improve soil structure and water-stable aggregates [7-10], help control various pests and weeds [11-13], maximize water and nutrient use efficiencies of crop production systems [11,14], and enhance net ecosystem productivity and longer-term carbon (C) sequestration. The effect is to potentially improve the yield of the subsequent cash crop [14-17]. They further provide forage for livestock [12], support pollinators and beneficial insects [11,12], and reduce water and air pollution [9].

Cover crops are presently being integrated into the temperate North American cash crop production systems $[18,19]$. In this region, cash crop farming mainly consists of planting corn (Zea mays L.) and soybean [Glycine $\max (\mathrm{L}$.$) Merril] in a 2$ year rotation (e.g., CS rotation) or alternatively, corn, soybean, 
and wheat (Triticum aestivum L.) in a 3 year rotation system (e.g., CSW rotation). Unfortunately, from August to April, depending on the cash crop, the ground is often bare. This creates potential for using cover crops to produce ecosystem services or to mitigate ecosystem dis-services associated with existing cropping system(s) [20]. Some examples of cover crops used in the region are: 1) red clover (Trifolium pratense L.), frost-seeded into winter wheat $[18,19,21]$, which can be terminated in late fall (or can be over-wintered under no-till condition), with corn planted in the following spring, and 2) oats (Avena sativa L.), seeded after winter wheat or cereal rye (Secale cereale L.) sown after corn or soybean, which are terminated in late-fall (i.e., November) or the following spring (i.e., April-May) prior to planting another main crop, usually corn or soybean [22,23].

Planting a single species of the cover crop has both benefits and disadvantages. Cover crop species such as oats and cereal rye produce excellent amounts of aboveground biomass, and they appear to be economic (e.g., low seed cost and high availability). However, they also come with certain drawbacks, e.g., they are not nitrogen-fixing; the biomass contains a higher C:N ratio compared to legumes; may produce low biomass if grown without supplemental nitrogen; may deprive the following cash crop of nitrogen [20,24-26]. On the other hand, red clover is a nitrogen-fixing legume which can be grown without additional $\mathrm{N}$ fertilizer. In addition, it over-winters (i.e., new growth can be seen in the spring) and produces higher quality biomass (with a lower C:N ratio) compared to non- $\mathrm{N}$-fixing grasses. The drawback associated with red clover is its non-uniform stand establishment, low volume of biomass produced, and high seed cost compared to grass cover crops such as oats and cereal rye $[19,25,27]$. Similarly, forage radish (Raphanus sativus L. var. longipinnatus) can be an excellent weed suppressor, and it reduces soil compaction; but it does not over-winter and hence does not provide a living root system or residue cover in the spring [28]. Hence, no single species can deliver all the benefits looked for in a cover crop, and therefore, planting of cover crop mixtures is gaining increasing attention to harness the complementary benefits of different cover crop species $[20,29,30]$.

The literature shows that growers have traditionally used single cover crops $[18,19,21,22]$. However, farmer groups and the private sector are expressing greater interest in multi-mix cover crops [26,31]. It is important that we choose suitable cover crop(s), an appropriate number of cover crops, as well as optimal ratios in multi-species mixes to diversify cover crop benefits. Unfortunately, limited literature is available which assesses the effects of sole covers and multi-mix species in temperate North America, which is the focus for this review. The first objective of this study is to review available studies on multi-mixes. As there are few such studies, the second objective is to specify criteria for selecting components of a multi-mix, while the third objective is to define future research needs in this area. A comprehensive review of the available literature from secondary sources (printed and on-line) on multi-mix research and their outcomes was performed for this study.

\section{Multi-mix Cover Crops Research and Outcomes}

The benefits of cover crops have been recognized for a long time; however, only a few studies have assessed multi-mixes in terms of agronomic, environmental, and economic indicators. A study conducted in Michigan, USA, involved three cover crops [red clover, hybrid sorghum Sudan grass (Sorghum bicolor $\times$ S. bicolor var. sudanense), and a multi-species mixture containing oats, soybean, lentil (Lens culinaris Medik.), forage pea/Austrian winter pea (Pisum sativum L. subsp. arvense), sweet clover (Melilotus officinalis L. Pall.), turnip (Brassica rapa subsp. rapa), oil-seed radish (Raphanus sativus L. subsp. Oleiferus), pearl millet (Pennisetum glaucum L.), and sunflower (Helianthus annuus L.)], which were compared to a fallow treatment [32]. The results demonstrated the effects of multi-mix species on the yield of the subsequent oat cash crop (i.e., $4.2 \mathrm{t} \mathrm{ha}^{-1}$ following the multi-species cover crop treatment compared to $3.9 \mathrm{t} \mathrm{ha}^{-1}$ following sorghum Sudan, and $3.5 \mathrm{t} \mathrm{ha}^{-1}$ following red clover or the fallow system). In addition, soil tests following the multi-species cover crop treatment showed a modest increase in phosphorus $(\mathrm{P})$, potassium $(\mathrm{K})$, magnesium $(\mathrm{Mg})$, calcium $(\mathrm{Ca})$ and Cation Exchange Capacity (CEC), while the soil organic matter, $\mathrm{pH}$ and lime index content were reduced compared to the sole cover crop treatment [32]. Similarly, Chu et al. [25] in a corn-soybean rotation system, compared 
multi-species cover crops [i.e., Natural Resources Conservation Service, United States Department of Agriculture (NRCS-USDA)'s soil health mix (SHM) for Tennessee, comprising cereal rye, oats, daikon radish (Raphanus sativus var. niger J. Kern.), purple top turnip (Brassica campestris L.), and crimson clover (Trifolium incarnatum L.)] over single-species cover crops (i.e., sole wheat and cereal rye), or double mixes [i.e., two-species mixtures of cereal rye + hairy vetch (Vicia villosa Roth.) or cereal rye + crimson clover], all compared to a no-cover control. They demonstrated that soybean yield, gravimetric soil water content, and soil inorganic nitrogen were higher in multi-species cover crop treatments than from single- and double-species cover cropping [25].

The benefits of cover crop mixtures were also reported by Snapp et al. [24], Couëdel et al. [13,33,34] and Mallinger et al. [35]. Snapp et al. [24] suggested that two different legume + cereal treatments [i.e., cowpea (Vigna unguiculata L) + Sudan grass (Sorghum sudanense L.); or red clover + wheat] or brassica + cereal mixtures, are the most effective means to produce substantial amounts of higher quality residues over a wide range of growing environments. Couëdel et al. $[13,33,34]$ also demonstrated that crucifer + legume mixes provided various ecosystem services (e.g., suppress soil pests, act as nitrate and sulphate catch crops) over monocultures. Mallinger et al. [35] compared 1, 2, 3, and 6 species cover crop mixes to one another and demonstrated that cover crops are valuable for pollinators. They further showed that there is a trade-off between mixes that attract a large number of managed bees versus mixes that attract fewer bees but ones that are rare [35].

Contrary to the above findings, Wortman et al. [36] did not observe any agronomic improvement (e.g., cash crop yields) as a result of increasing the number of cover crop species (i.e., 2, 4, 6, and 8 species mix) in a sunflower-soybean-corn rotation system. Also, Smith et al. [37] did not find any benefits of a five-species annual cover crop mixture in terms of biomass stability, weed suppression, and yield of the subsequent cash crop (e.g., oats) compared to the best-performing sole cover crop. Finney et al. [38] demonstrated increased weed suppression and reduced nitrate $\left(\mathrm{NO}_{3}{ }^{-}\right)$leaching with mixtures but these did not improve the yield of the subsequent cash crop. They demonstrated that post-wheat cover crop mixtures (i.e., 3, 4, and 6 species mix) tend to have greater multi-functionality than monocultures but certain monocultures provide similar (e.g., oats, radish) or greater (e.g., pea) multi-functionality than diverse mixtures. McGuire [39] suggested that the best cover crop is a monoculture, not mix, considering the extra expense (mainly seed), time (modifying and setting up planting equipment), and, especially, the extra management needed to obtain a diverse stand. Sanderson et al. [40] also tested four mixtures dominated by one species, six mixtures dominated by pairs of species, and one equal mixture over four monocultures, and concluded that annual forage mixtures did not yield more forage than the most productive monoculture. Stewart [22] also found little evidence to suggest that cover crop mixtures (i.e., 3 and 10 species mix) produced more biomass than sole cover crops (e.g., oats, red clover). The poor performance of some mixes could be the result of the short-term nature of some of the studies (i.e., one or two cropping seasons) and/or the specific composition of species in some of the mixtures (i.e., lack of functional complementarity) [20,38].

\section{Criteria for Developing a Complementary Cover Crop Mixture}

Complementary cover crop mixtures enhance cover crop multi-functionality (e.g., addition of carbon biomass, weed suppression, pest suppression, nitrogen retention, nitrogen supply, cash crop production, profitability), although some trade-offs exist [20,38]. Therefore, emphasis should be placed on increasing the functional diversity/multi-functionality of cover crop mixtures which helps ameliorate disservices associated with certain monocultures [20]. Major cover crops in temperate North America, and their key characteristics or services that are required to increase multi-functionality of cover crop mixtures are summarized (Table 1, Figure 1). In addition, planting windows and termination methods of major cover crops that need to be considered while developing a mixture are listed (Table 2). To ensure multiple benefits of growing cover crops, it is important that the selected species have long-term effects, including protection of soil and the environment, and uptake and storage of plant nutrients between seasons when available nutrients are prone to leaching $[3,24,26]$. These criteria are briefly discussed below: 
Table 1. Summary of various services and characteristics of cover crops to enable multi-mix composition selection (source: modified from Penn State Extension [26] and the Natural Resources Conservation Service, United States Department of Agriculture [31]).

\begin{tabular}{|c|c|c|c|c|c|c|c|c|c|c|c|c|c|c|c|c|c|c|c|c|c|c|}
\hline \multirow[b]{2}{*}{ Cover Crop Species } & \multicolumn{22}{|c|}{ Selection Criteria/Services/Characteristics } \\
\hline & 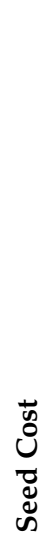 & 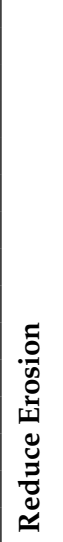 & 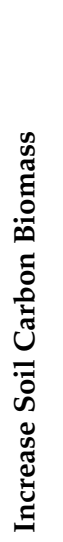 & 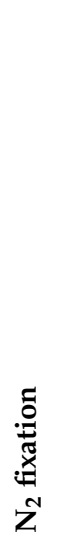 & 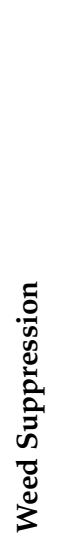 & 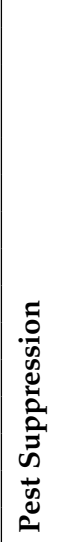 & 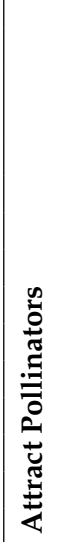 & 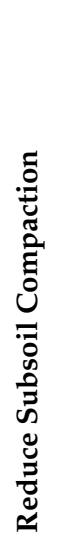 & 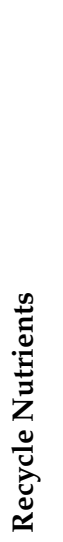 & 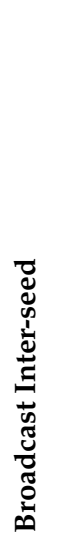 & 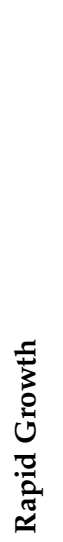 & 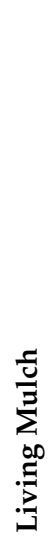 & 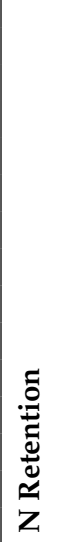 & 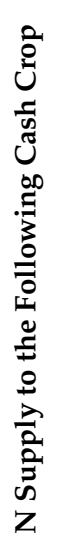 & 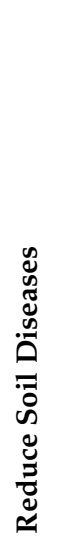 & 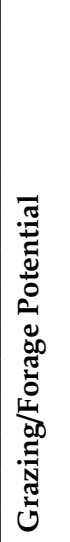 & 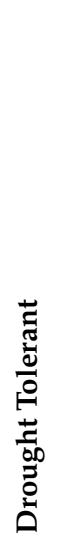 & 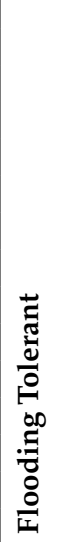 & 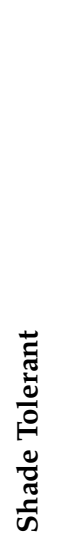 & 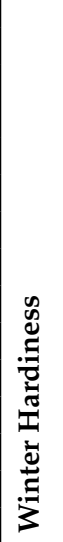 & 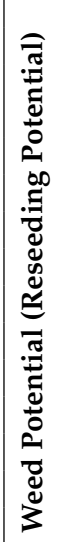 & 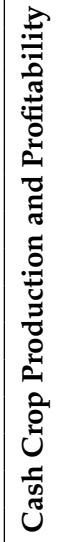 \\
\hline \multicolumn{23}{|l|}{ Cool Season Grains } \\
\hline $\begin{array}{c}\text { Cereal Rye } \\
\text { (Secale cereale L.) }\end{array}$ & - & ++ & ++ & & ++ & & & & ++ & + & + & & ++ & - & + & ++ & + & - & + & ++ & + & $-/+$ \\
\hline $\begin{array}{c}\text { Oats } \\
\text { (Avena sativa L.) }\end{array}$ & - & - & ++ & & ++ & $-/+$ & & & - & - & ++ & - & ++ & $-/+$ & - & ++ & & - & & & & + \\
\hline \multicolumn{23}{|l|}{ Warm Season Grains } \\
\hline $\begin{array}{c}\text { Buckwheat } \\
\text { (Fagopyrum esculentum L.) }\end{array}$ & - & & - & & ++ & $-/+$ & ++ & & ++ & & ++ & & + & + & & & & & & & ++ & + \\
\hline $\begin{array}{c}\text { Sorghum/Sudan grass } \\
\text { (Sorghum bicolor } \times \text { S. bicolor var. sudanense) }\end{array}$ & + & ++ & ++ & & ++ & $-/+$ & & ++ & ++ & & ++ & & + & + & ++ & + & ++ & - & - & & - & + \\
\hline \multicolumn{23}{|l|}{ Legumes } \\
\hline $\begin{array}{c}\text { Red Clover } \\
\text { (Trifolium pratense L.) }\end{array}$ & + & - & + & + & - & $-/+$ & + & + & + & ++ & & - & + & + & & ++ & & - & + & ++ & & + \\
\hline $\begin{array}{c}\text { Crimson Clover } \\
\text { (Trifolium incarnatum L.) }\end{array}$ & + & + & + & + & & $-/+$ & + & & & ++ & - & - & + & + & & ++ & & + & + & - & ++ & + \\
\hline $\begin{array}{c}\text { Hairy Vetch } \\
\text { (Vicia villosa Roth.) }\end{array}$ & + & - & ++ & ++ & + & $-/+$ & + & - & - & + & & - & + & ++ & - & - & - & & - & + & - & + \\
\hline $\begin{array}{c}\text { Forage Pea/ } \\
\text { Austrian Winter Pea } \\
\text { (Pisum sativum L. } \\
\text { subsp. arvense) }\end{array}$ & + & + & + & ++ & & $-/+$ & + & & & & + & & + & ++ & + & + & - & & & & & + \\
\hline
\end{tabular}


Table 1. Cont

\begin{tabular}{|c|c|c|c|c|c|c|c|c|c|c|c|c|c|c|c|c|c|c|c|c|c|c|}
\hline \multirow[b]{2}{*}{ Cover Crop Species } & \multicolumn{22}{|c|}{ Selection Criteria/Services/Characteristics } \\
\hline & $\begin{array}{l}\overrightarrow{0} \\
\dot{0} \\
\vec{\Xi} \\
\dot{\varpi}\end{array}$ & 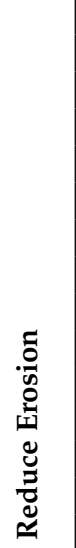 & 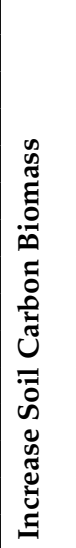 & 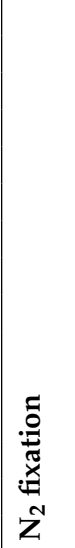 & 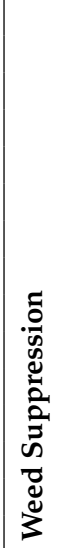 & 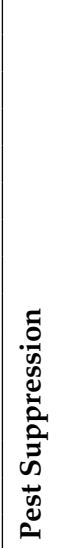 & 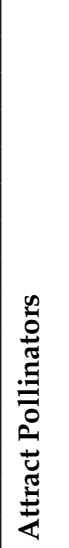 & 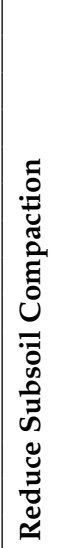 & 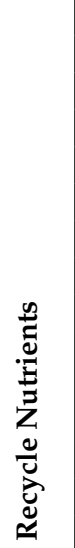 & 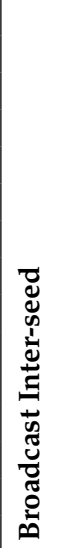 & 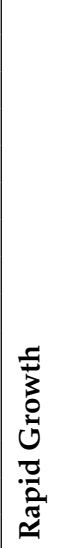 & 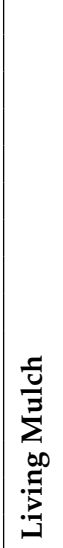 & 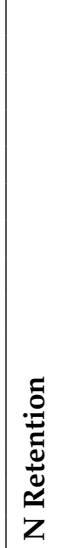 & 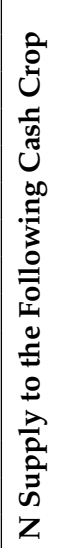 & 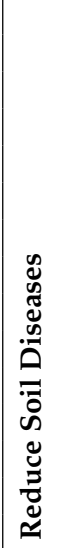 & 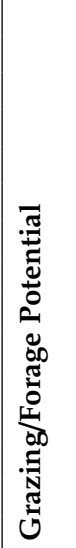 & 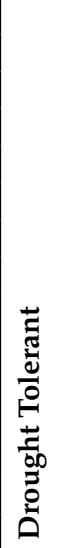 & 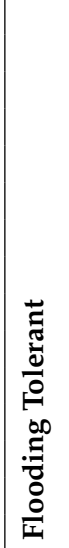 & 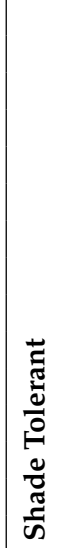 & 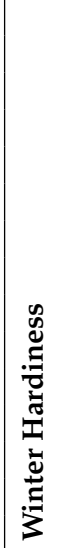 & 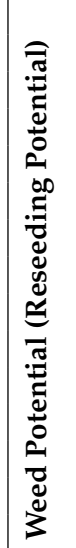 & 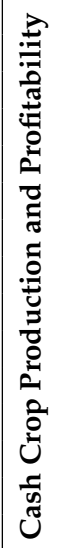 \\
\hline $\begin{array}{c}\text { Alfalfa } \\
\text { (Medicago sativa L.) }\end{array}$ & + & + & ++ & ++ & & $-/+$ & + & ++ & & & & & + & + & & ++ & & & & + & & + \\
\hline \multicolumn{23}{|l|}{ Oilseeds } \\
\hline $\begin{array}{c}\text { Forage Radish } \\
\text { (Raphanus sativus L. var. longipinnatus) }\end{array}$ & + & + & + & & ++ & + & & ++ & ++ & + & + & & + & $-/+$ & + & - & & & - & & - & + \\
\hline $\begin{array}{c}\text { Purple Top Turnip } \\
\text { (Brassica rapa L. subsp. rapa) }\end{array}$ & + & + & + & & ++ & + & & ++ & ++ & + & + & & + & $-/+$ & + & - & & & - & & - & + \\
\hline $\begin{array}{c}\text { Canola } \\
\text { (Brassica napus L.) }\end{array}$ & ++ & + & + & & - & + & ++ & & + & + & + & & + & $-/+$ & ++ & - & + & & - & & ++ & $-/+$ \\
\hline $\begin{array}{c}\text { Sunflower } \\
\text { (Helianthus annuus L.) }\end{array}$ & ++ & + & + & & - & + & ++ & & - & & + & & + & $-/+$ & & & & & & & & $-/+$ \\
\hline \multicolumn{23}{|l|}{ Grasses } \\
\hline $\begin{array}{c}\text { Annual Ryegrass } \\
\text { (Lolium multiflorum Lam.) }\end{array}$ & - & ++ & ++ & & ++ & & & & ++ & ++ & + & + & ++ & + & - & ++ & & + & + & & ++ & + \\
\hline $\begin{array}{l}\text { Perennial Ryegrass } \\
\text { (Lolium perenne } \mathrm{L} .)\end{array}$ & - & ++ & ++ & & + & & & & ++ & ++ & + & + & ++ & $-/+$ & - & ++ & & + & + & & + & + \\
\hline
\end{tabular}


Table 2. Cropping system compatibility and required termination methods for major cover crop species used in temperate North America (source: modified from the Natural Resources Conservation Service, United States Department of Agriculture [31]).

\begin{tabular}{|c|c|c|c|c|c|c|c|c|c|c|c|c|}
\hline \multirow{2}{*}{$\begin{array}{l}\text { Cover Crop } \\
\text { Species }\end{array}$} & \multirow{2}{*}{$\begin{array}{c}\text { Seeding } \\
\text { Depth }(\mathrm{cm})\end{array}$} & \multicolumn{6}{|c|}{ Planting Season } & \multicolumn{5}{|c|}{ Termination Method } \\
\hline & & Spring & $\begin{array}{c}\text { Early } \\
\text { Summer }\end{array}$ & Summer & Early Fall & Fall & Frost & Mow & Till & Crimp & Winterkill & Chemical \\
\hline \multicolumn{13}{|l|}{ Cool Season Grains } \\
\hline Cereal Rye & $2.5-5$ & & & & + & ++ & & + & + & + & & + \\
\hline Oats & $1.5-3$ & ++ & & & ++ & & - & - & ++ & + & ++ & + \\
\hline \multicolumn{13}{|c|}{ Warm Season Grains } \\
\hline Buckwheat & $1.5-3$ & & ++ & ++ & + & & & + & ++ & ++ & ++ & + \\
\hline $\begin{array}{c}\text { Sorghum/Sudan } \\
\text { grass }\end{array}$ & $1.5-3$ & & ++ & ++ & + & & & & + & & ++ & + \\
\hline \multicolumn{13}{|l|}{ Legumes } \\
\hline Red Clover & $1-1.5$ & ++ & + & & + & & + & & + & & & + \\
\hline Crimson Clover & $1-1.5$ & ++ & ++ & + & + & & - & + & + & + & - & + \\
\hline Hairy Vetch & $1.5-3$ & & & & ++ & & - & - & + & + & - & + \\
\hline Forage & & & & & & & & & & & & \\
\hline $\begin{array}{l}\text { Pea/Austrian } \\
\text { Winter Pea }\end{array}$ & $2.5-7$ & ++ & + & & ++ & & & ++ & ++ & + & ++ & + \\
\hline Alfalfa & $0.5-1$ & ++ & & & + & & & & + & & - & + \\
\hline \multicolumn{13}{|l|}{ Oilseeds } \\
\hline Forage Radish & $1-1.5$ & ++ & + & & ++ & & + & + & ++ & + & ++ & + \\
\hline Purple Top Turnip & $1-1.5$ & ++ & + & & ++ & & + & + & ++ & + & ++ & + \\
\hline Canola & $1-1.5$ & ++ & + & & ++ & & + & - & + & + & + & + \\
\hline Sunflower & $2.5-5$ & ++ & + & & ++ & & & + & + & + & ++ & + \\
\hline \multicolumn{13}{|l|}{ Grasses } \\
\hline Annual Ryegrass & $0.5-1$ & ++ & + & - & ++ & & & + & ++ & & - & + \\
\hline Perennial Ryegrass & $0-1$ & ++ & & - & ++ & & & & ++ & & - & + \\
\hline & & Reliabil & bove $A$ & ge $(++)$ & age $(+), \mathrm{B}$ & vel & ind $B$ & $\operatorname{Not} R$ & nded & & & \\
\hline
\end{tabular}




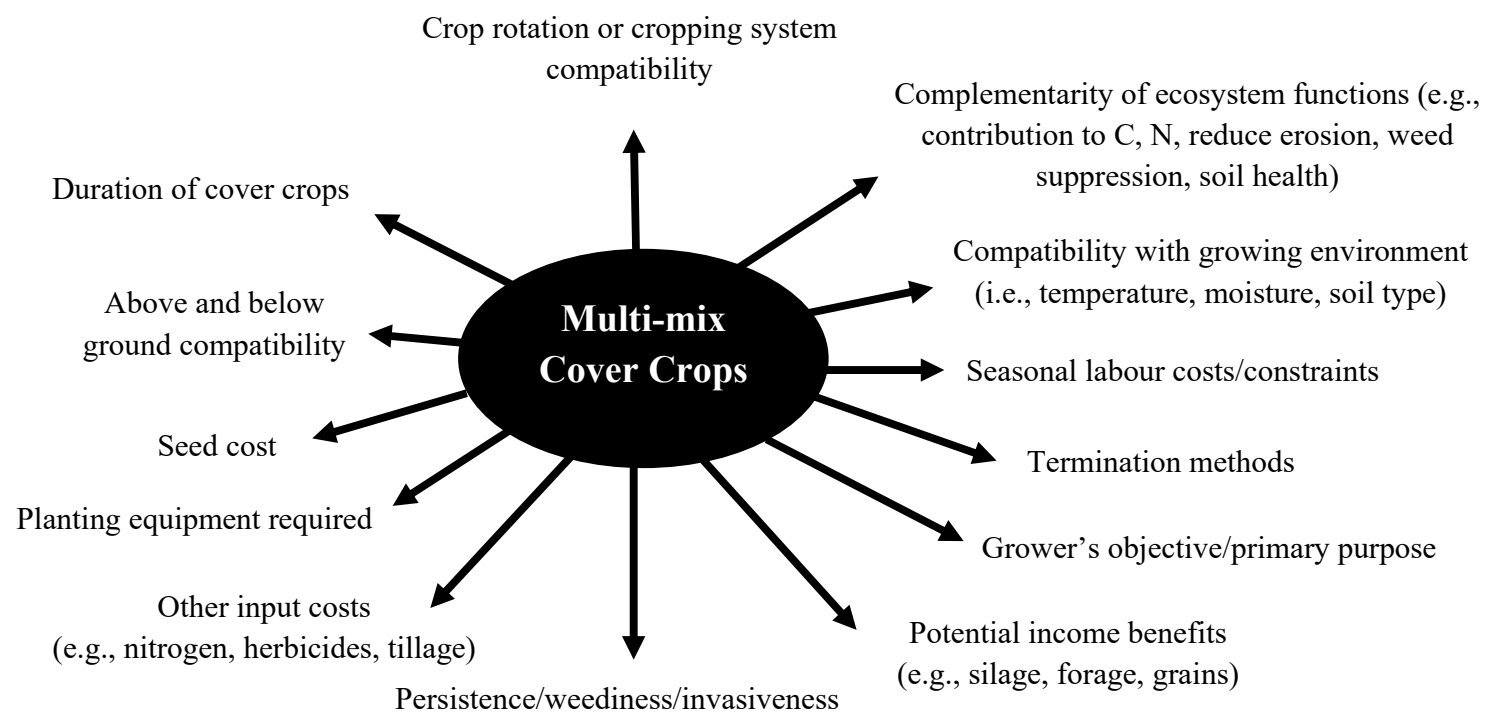

Figure 1. Criteria for selecting components of a multi-mix cover crop.

\subsection{Grower Objectives/ Primary Purpose of Planting the Cover Crop}

The selection of cover crops depends on the objectives of the growers (e.g., need for $\mathrm{C}$ or $\mathrm{N}$, better canopy cover to protect soils, weed suppression, reduced soil compaction). For example, cereals (e.g., oats) produce a large volume of biomass and add significant amounts of $C$ to soils and should be considered if the objective is to rapidly build soil organic matter. Legumes (e.g., red clover, hairy vetch) fix N, produce high-quality biomass, and enhance beneficial organisms, and hence they are considered as the most reliable means to enhance cash crop yields. Brassicas [e.g., canola, mustard (Brassica nigra L.), radish (Raphanus sativus L.], on the other hand, are good at attracting pollinators [35], producing glucosinolate-containing residues, and suppressing plant-parasitic nematodes and soil-borne disease $[13,33,34]$. Hence, they should be planted if soil pests are a major yield-limiting factor in cash crop production.

Selection of cover crops could be different for dual-purpose cover crops that are grown and harvested for economic value (e.g., grains, biomass) [41,42]. Winter wheat is often selected over cereal rye because of greater flexibility for grain harvest; however, cereal rye seed is becoming more valuable with increased demand for cover cropping seed [43]. These options come with varying levels of risk, although all are quite feasible regionally when varieties and management practices are adjusted to fit the prevailing growing environment $[44,45]$.

\subsection{Crop Rotation and Cropping System Compatibility}

The choice of cover crop species is also determined by the crop rotation systems (e.g., CS or CSW systems) and the type of cash crops grown, since these factors determine the window available for the growth of cover crops $[5,30]$. In general, most cover crops require $40-60$ days of growth to maximize fall biomass production before a killing frost [46]. There is a long enough (a maximum of $2 \frac{1}{2}$ months) fall growing season in temperate North America following winter wheat harvest in late-July/early-August for full season cover crops to reach the early stages of reproductive development $[18,19]$; however, the growing season will typically observe limited growth after soybean and corn harvests (as little as 2 weeks in some years) in September to October [27,47]. The early sowing in corn-soybean rotations remains a challenge. However, attempts to inter-seed cover crops [e.g., cereal rye, annual ryegrass (Lolium multiflorum Lam.), clovers] into corn have been somewhat successful [47]. 


\subsection{Above and Belowground Compatibility}

Cover crops differ in their growth forms (e.g., straight/erect or spreading growth type), canopy coverage (e.g., tall and open canopies or short and dense canopies or vining) and rooting depth and architecture $[24,26]$. Hence, while selecting cover crop species in a mixture, emphasis should be given to complementary species that minimize competition between species for space, light, nutrients, moisture, and shading (Figure 2) [22]. It is likely that cover crop species with similar growth forms compete with each other while species with differing growth forms are more likely to be complementary [26]. For example, cover crops with an upright growth habit (e.g., cereal rye, oats, sorghum Sudan) can be better combined with trailing types (e.g., winter pea, hairy vetch). Furthermore, although cereal rye and crimson clover belong to different groups, they may compete for the same space in the fall. In that situation, replacing crimson clover with winter pea may create a more complementary mixture, as rye provides support for the climbing habit of pea. Cover crop species such as oats, cereal rye, sorghum Sudan grass, and forage radish are highly competitive against other species in a mixture [26]. The dominance of these species can be prevented by reducing their seeding rates compared to when they are planted as monocultures or by planting them in an alternating row configuration [26].

\subsection{Complementarity of Ecosystem Functions}

Cover crops also differ in their soil coverage, amount of carbon they contribute to soils, ability to fix atmospheric nitrogen, attract/host pollinators and beneficial organisms, build soil health through increased microbial activities, soil $\mathrm{N}$ acquisition strategies, and in their ability to supply $\mathrm{N}$ to the following cash crop (Table 1) $[3,9,15,16,20,34,38]$. As noted already, cereals (e.g., oats, cereal rye) contribute more $\mathrm{C}$ to soil while legumes (e.g., red/crimson clover, hairy vetch, winter pea) add more $\mathrm{N}$. Similarly, some species [e.g., sunflower, buckwheat (Fagopyrum esculentum L.), crimson clover] attract pollinators $[22,26,35]$ while radish and rapeseed (Brassica napus L.) provide better soil coverage as well as reduce soil compaction [28] (Table 1). Hence, a cover crop mixture should be designed in a way that maintains the balance between species (e.g., cereals, legumes, brassicas) to take maximum advantage of diversity and ecosystem services while also considering trade-offs: as some services increased, other disservices arose, limiting multi-functionality [20,25,29,30,38]. For example, over-wintering non-legume cover crops (e.g., cereal rye) exhibit more extreme trade-offs, in which high $\mathrm{N}$ retention potential is often associated with $\mathrm{N}$ immobilization during the cash crop phase [20]. Trade-offs between $\mathrm{N}$ retention and $\mathrm{N}$ supply can be managed by developing a complementary mixture which manipulates the mixture's C:N ratio [20,38].

\subsection{Compatibility with the Growing Environment}

The selection of cover crop differs with the growing environment (i.e., location, temperature, moisture availability). The late summer and fall in the east and north of the Great Lakes (i.e., Michigan, Pennsylvania, Ontario) tend to be fairly cool and moist (with average temperature and precipitation of $45^{\circ} \mathrm{F}$ and $15 \mathrm{~cm}$, respectively, from September to November) while the late summer and fall in the south and west of the Great Lakes (e.g., Illinois, Indiana, Ohio, Minnesota, Wisconsin) tend to be fairly dry [23,48]. With cooler temperatures to the east and north, there is very little growing season left after corn or soybean harvest before a killing frost, narrowing the options for integration of fall planted cover crops even when soil moisture is high [23]. On the other side (i.e., to the west and south of the Great Lakes), despite a slightly longer growing season, low soil moisture can be the limiting factor for cover crop germination and establishment [49]. In general, crops such as oats, cereal rye, crimson clovers or vetch are commonly planted as post-cash crop harvest winter cover crops in the fall [22,50], while some legumes such as red clover can be frost-seeded into winter wheat or inter-seeded into spring wheat during early to late spring $[19,21]$. Also, within temperate climates, warm-season $C_{4}$ grasses (e.g., sorghum Sudan) are outstanding performers for the summer season, while cereal rye is the most promising for the winter season [24]. 


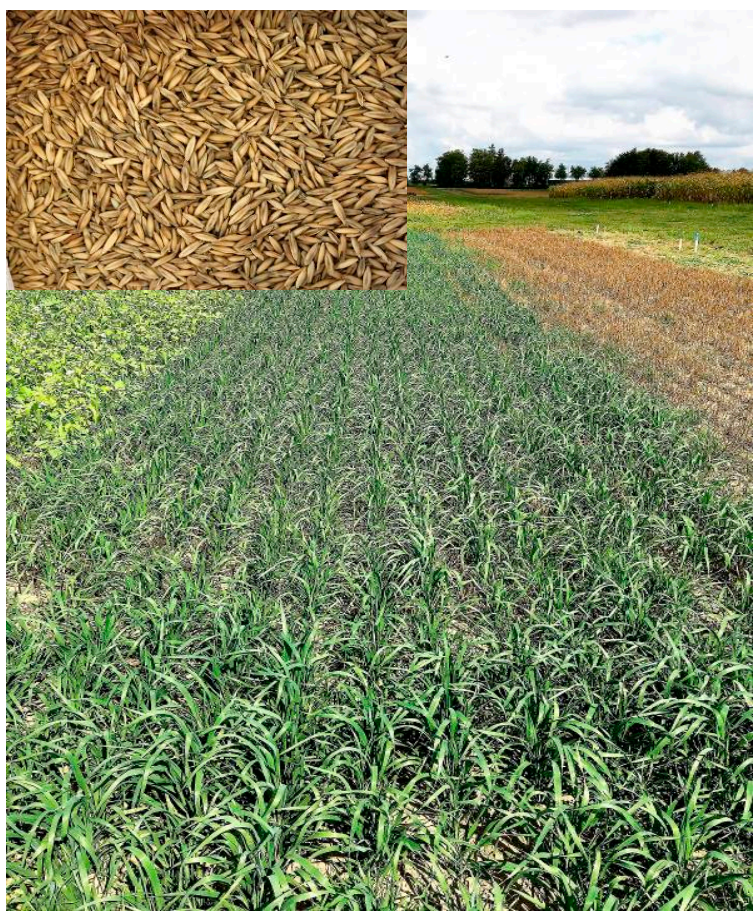

(a)

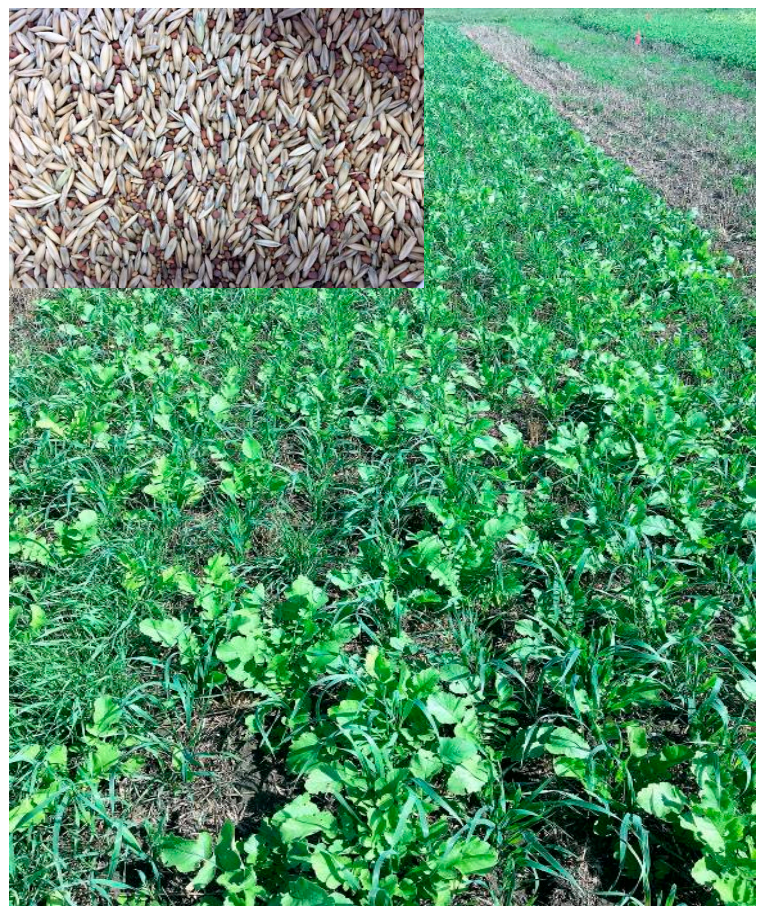

(c)

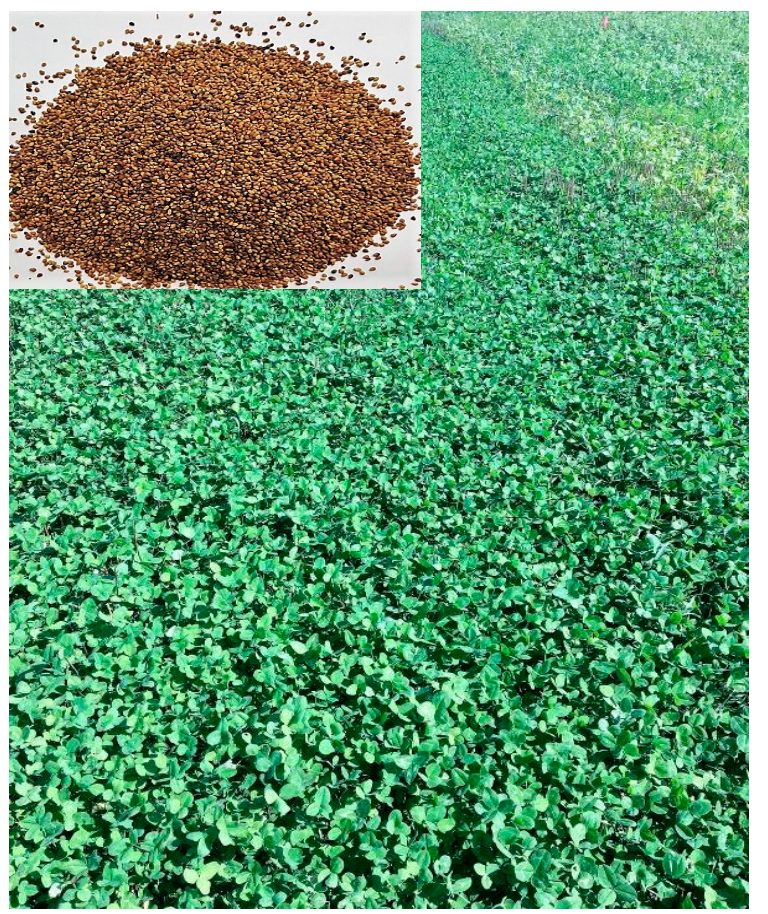

(b)

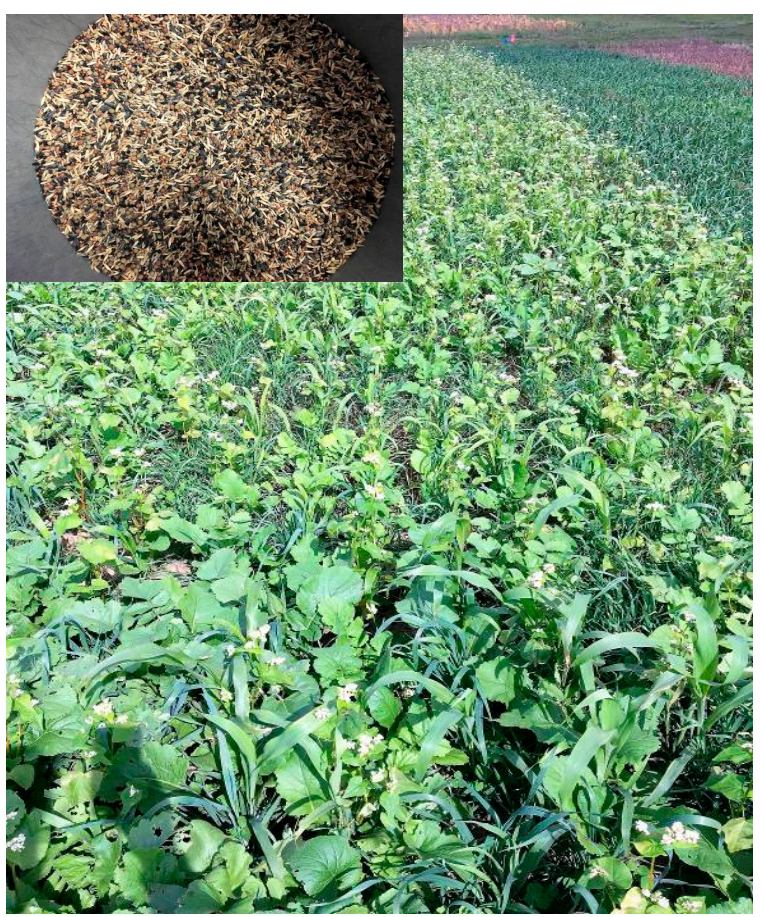

(d)

Figure 2. Example pictures of sole and multi-mix cover crops: (a) sole oats; (b) sole red clover; (c) three-way mixes involving oats, crimson cover, daikon radish; (d) 10 way mixes involving oats, cereal rye, buckwheat, sorghum Sudan, crimson clover, hairy vetch, Austrian winter pea, daikon radish, purple top turnip, and sunflower. 


\subsection{Duration of Cover Crops}

The growth period (i.e., duration between planting and terminating time) plays an important role in selecting an appropriate species in mixtures. As noted earlier, cover crops that do not over-winter (e.g., oats, buckwheat) can be planted early (early fall) compared to those that over-winter (cereal rye, vetch, etc.). This duration also affects the amount of biomass produced by different cover crops: the longer they stay in the field during the growing season, the more biomass they produce $[5,26]$. The best strategy could be to mix both types (winterkilling as well as over-wintering species) in order to obtain sufficient ground cover in the fall and spring.

\subsection{Termination Method}

The other factor that determines the selection of cover crops is the termination strategy: either by using cover crops as live mulch for establishing subsequent grain/food crops or by killing cover crops chemically (using herbicide, e.g., RoundUp) or mechanically (e.g., rolling/crimping or tillage) before the grain/food crop is planted [3,36,51]. The first option is possible if the selected cover crops do not compete with the cash crops. Table 2 lists many of the common cover crop species used in temperate North America, their functional groupings as well as planting windows and termination methods.

Some cover crops (e.g., oats, buckwheat, sorghum Sudan, winter pea, sunflower, forage radish, turnip, sunflower) are easily killed by winter while some others (e.g., cereal rye, red clover, annual ryegrass, hairy vetch) can over-winter and often produce a dense canopy of rapidly maturing plants in the spring [22]. Termination of these cover crops using herbicide could be a challenge when combined with the typically cool temperatures in April/May, leaving opportunity for some species of developing herbicide resistance or they may become weeds if not properly controlled prior to planting the primary cash crops [26,51]. Termination using tillage is an option, but multiple tillage passes may be necessary which can negate the benefits that the cover crop is providing to soil health which could result in erosion [51,52]. Hence, selection of cover crops with reliable winter sensitivity (e.g., winterkill) along with a few over-wintering species could be a better strategy to diversify cover crop benefits in the fall and spring.

\subsection{Input Costs}

Seeds are considered as the major cost involved in cover cropping strategies $[24,36,37,53]$. Some cover crops (e.g., brassicas) are expensive compared to legumes and cereals. On the other hand, legume covers are considered as slow growers and expensive to establish compared to cereals [24]. In general, cereals/grasses are inexpensive and are commonly used by growers in temperate North America. Apart from seeds, other input costs (e.g., nitrogen fertilizer for better growth and biomass production, and herbicides for termination) also play important roles while selecting cover crop species. The seed cost of the cereals/grasses could be cheaper, but they may require supplemental nitrogen to achieve satisfactory growth compared to legumes.

\subsection{Planting Equipment Required}

Seeding depth, spacing and row configuration may differ among different cover crop species [26]. The drills that are equipped with a large box (for large-seeded crops such as oats, cereal rye, pea) and a small box (for small-seeded crops like clovers, purple top turnip, radish) can be used for different seeding depths (shallower or deeper) by handling the drop tubes. In that situation, cover crop species can be split into separate boxes according to seed size and planting depth and planted as one pass of the drill. For a drill with a single seedbox, the mixture can be planted using the same box but it would be necessary to calibrate the notch number/hole size and seeding depth to ensure that both large-seeded and small-seeded cover crops drop at the correct rate and depth to obtain uniform stands and desired species composition. The latter technique, however, is not the most effective strategy to obtain the optimum seeding rates/depths for various species in a mixture. Another consideration 
would be to sow the large-seeded species with a drill and make a second pass for small-seeded species with a broadcast seeder followed by a cultipacker. This consumes more time but can be combined into one piece of equipment by using a custom-rigged tractor with a broadcast spreader on the front [26].

\subsection{Persistence/Weediness/Invasiveness}

Winter cover crops (e.g., annual ryegrass, red clover, hairy vetch,) may become weeds if they are not properly controlled prior to planting the primary cash crops [26,51]. Some major reasons for cover crop persistence can include delayed seed dormancy, hard seededness, self-regeneration (e.g., seeding in the spring), herbicide tolerance, and production of rhizomes [51,54,55]. For example, seed dormancy or hard seededness can lead to delayed germination, which increases the chance that the cover crop will become a weed [55]. Both hairy vetch and ryegrass have the potential to set dormant seed and become persistent weeds. Many leguminous cover crops and perennial forages also carry some level of hard seededness [54]. Therefore, potential challenges involved in terminating different species in a mixture should be considered to ensure that the field is free of volunteer crops/weeds for the following season.

\subsection{Opportunities to Utilize as a Forage or for Grazing/Other Income Benefits}

Growers are ultimately more interested in the crops that are associated with higher net economic gain: specifically if the producer can capture value through grazing the cover crop, using the cover crop as a source of late fall or early spring forage, by making high-quality silage or through harvesting the seed [24,36]. Ryegrass, barley, and wheat are some grasses foraged in temperate North America, but oats and cereal rye remain the gateway cover crop for most producers: they require minimal inputs, perform consistently/are the most dependable, have the earliest harvest window of any annual grass species, and produce approximately $>2 \mathrm{Mg}$ dry matter of high-quality livestock forage by flag to early head stages [56-58]. Also, winter canola (Brassica rapa L.), pennycress (Thlaspi arvense L.), or camelina (Camelina sativa L.) can be planted in the fall (mid-September), which over-winter and can be harvested in late-June-July, and then a shorter season soybean can be planted [41,47]. It is important to note that there could be several other associated benefits (e.g., environmental, soil health, potential yield gains of the cash crop in the following season) with multi-mixes that need to be converted into economic values while calculating the net income benefits.

\subsection{Seasonal Labour Costs/Constraints}

Other factors to consider are labour costs/constraints while developing a mixture, modifying and setting up planting equipment/a custom-rigged tractor, and sowing the large-seeded and small seeded species by making two different passes $[24,26,39]$. These activities consume more time compared to the management of sole covers [24,39], which may discourage growers from using multi-mixes, especially in regions where labour shortage is a critical production constraint. Labour cost can be minimized if mixtures are planted using the same planting box or by using two separate boxes on the same planter for cover crop seeds of very different sizes [26].

\section{Method/Step-wise Procedures for Developing a Complementary Mixture}

A summary of various services or characteristics of cover crops to enable multi-mix composition selection is provided (Table 1). The list below summarizes step-wise procedures that may be useful in developing cover crop mixtures considering the cash crop production system in Southwestern Ontario, Canada, as an example:

Step 1: Identify the primary field crops or crop rotation system in which cover crops are to be introduced: for example, in Southwestern Ontario, two major cash crop rotation systems involve corn-soybean (CS) and corn-soybean-winter wheat (CSW) rotation systems [19,22]. Hence, appropriate cover cropping 
strategies involve post-wheat cover crops in CSW, post-soybean cover crops in CS and post-corn cover crops in CS or CSW rotation systems.

Step 2: Determine the time window or duration between the primary crop production cycles that is available for cover crop growth. For example, in Southwestern Ontario, winter wheat is harvested in late-July to early-August while soybean and corn are harvested in September-October (depends on location and varieties used) and hence the planting window for post-wheat cover crops starts from August till the following spring (March-April), while for post-soybean and post-corn cover crops, the planting windows are available from October to the following spring $[19,22,27,47]$.

Step 3: List the cover crop species for which seeds are potentially available in the region: Tables 1 and 2 summarize potential cover crops available in Southwestern Ontario, their planting times, and associated benefits. Some additional crops that can be used as cover crops in the region include soybean, lentil, sweet clover, pearl millet, wheat, triticale (x Triticosecale) [26].

Step 4: Narrow down the list of candidate cover crops by considering the criteria discussed in Section 3 . Those involve objectives or services required as well as strengths and weaknesses of each cover crop species in terms of planting date, environmental suitability, seed cost and availability, complementary growth periods and growth habits, nutrient acquisition strategies, and option(s) available for cover crop termination, etc. Priority should be given to over-wintering species (e.g., cereal rye, clovers) as post-soybean or post-corn cover crops due to a narrower window available for fall growth [26].

Step 5: Develop mixtures (e.g., 2 species or higher) by considering the number of species included in the mixture, seed size, planting method (no-till drilling or broadcast), and competitiveness of selected species. For example, a potential post-wheat three-way multi-mix may involve oats, red clover (or winter pea) and radish while a 10 way mix can involve the cool season grains (e.g., oats, cereal rye), warm-season grains (e.g., buckwheat, sorghum Sudan), legumes (e.g., clover, hairy vetch, winter pea), and oilseeds (e.g., radish, turnip, sunflower or canola) (Figure 2) [22]. Post-corn or post-soybean cover crops may involve cereal rye or annual ryegrass as sole covers or mixed with clover [22]. While developing the mixture, one of the methods to determine the mixing ratio involves dividing the recommended seeding rate for each species by the number of species in the mixture [59,60].

Step 6: Plant a cover crop or a mixture at the appropriate time. A common strategy is to plant winter cover crops following the cash crop harvest in the early fall (e.g., post-wheat, -corn or -soybean) to utilize residual moisture. To avoid volunteer crops, it may be better to wait for a few days/weeks following the winter wheat harvest, allow the leftover seeds to germinate, and then terminate them using appropriate control measures, followed by planting the cover crop mixture. Alternatively, some cover crops (e.g., annual ryegrass) can be inter-seeded/drilled between rows of corn during the V7-V8 growth stage of corn or can be inter-seeded (e.g., cereal rye) into corn one month after silking (i.e., Kernel Dent Stage or R5 stage). Similarly, cereal rye can be inter-seeded into soybean at leaf yellowing to $50 \%$ leaf drop stage. Also, red clover can be inter-seeded or frost-seeded into winter wheat during early spring (e.g., March-April) in temperate North America [18,19,21,22].

Step 7: It is important to terminate cover crops at the correct time. Some options include fall termination by using a mouldboard plow/chisel or let them stay on the soil surface over winter, or termination in the spring using herbicides followed by no-till or strip-till planting [22,36,51,52]. Better quality biomass (with a lower C:N ratio in cereal cover crops) can be obtained when these cover crops are terminated while green. This strategy further prevents cereal covers from producing seeds that could become weeds in the following season.

Step 8: Building an appropriate cover crop mixture is a continuous process. Species composition may vary between years and location (soil types, moisture conditions, etc.), which may affect functional diversity/multifunctionality of cover crop mixtures [20,22], and therefore, continuous observation 
of the species composition and associated ecosystem services is suggested along with any needed adjustment(s) in the species mix.

\section{Conclusion and Future Needs}

Different cover crops offer a different suite of benefits. Cover crop mixtures can be considered as a key tool for enhancing the multi-functionality, resiliency, and sustainability of cropping systems in temperate regions. However, the benefits from multi-mix species depend on the selection of cover crop species based on the criteria discussed in this manuscript. Hence, research is required that is focused on the following key questions that growers and researchers in temperate North America are currently unable to answer effectively:

- Is planting a multi-mix advantageous compared to sole covers? If yes, how many species should be in the mix? It is said that increasing the number of species does enhance important ecosystem functions, but after a certain point, adding additional species may no longer provide additional benefits or they may not yield more forage than the most productive monoculture.

- Can inclusion of cover crops in a simple rotation (e.g., corn-soybean) provide equivalent agronomic, soil health and environmental benefits as documented for more complex rotations with or without cover crops (i.e., to what extent can cover crops mitigate problems associated with a poor rotation)?

- What benefits do cover crops provide after 2-3 years of use, specifically agronomic benefits (i.e., yield, yield stability, drought resilience, nutrient requirements, and net economic returns), soil health benefits (i.e., organic matter, aggregate stability, rhizosphere and endophytic microbial diversity, soil water holding capacity, soil health tests) and environmental benefits (i.e., carbon sequestration through organic matter increases, reduced nitrogen losses, reduced susceptibility to soil erosion, reduced susceptibility to phosphorus losses, pollinator habitat)? What are the benefits after 10-15 years of use? How does cover crop composition (sole covers, multi-species mix) affect short- and long-term benefits from cover crops?

- For a given cover crop mixture, how stable are the biomass and species composition of the biomass across locations and years? This challenge may require creating functional redundancy (e.g., to create homogeneous functional mixture in the field) in cover crop polycultures.

Addressing these questions requires long-term platforms to evaluate different cover cropping strategies (both sole as well as multi-mix) as part of simple-to-complex rotation systems. The cover crop strategies should be tested with different tillage strategies (plow-till, no-till or strip-till) depending on the needs of local growers and the growing conditions.

Author Contributions: Author T.C. designed the study, managed the literature review, and produced the first draft of the manuscript. Authors E.A.L. and M.N.R. provided support in all phases of this review. All authors have read and agreed to the published version of the manuscript.

Funding: This study was supported by the Food from Thought research program at the University of Guelph, funded by the Canada First Research Excellence Fund. Also, funding was received from the Ontario Ministry of Agriculture, Food and Rural Affairs (OMAFRA) and Grain Farmers of Ontario (GFO).

Acknowledgments: We would like to thank the Food from Thought research program at the University of Guelph funded by the Canada First Research Excellence Fund. We thank our partners, the Ontario Ministry of Agriculture, Food and Rural Affairs (OMAFRA) and Grain Farmers of Ontario (GFO), for funding the Long-Term Cover Crops project (LTCC). We express our sincere thanks to Prof. Bill Deen, Prof. Dave Hooker, Mr. Matt Stewart, Mr. Godfrey $\mathrm{Chu}$, and other researchers involved in this project.

Conflicts of Interest: The authors declare no conflict of interest.

$\begin{array}{ll}\text { Abbreviations } \\ \mathrm{C} & \text { Carbon } \\ \mathrm{Ca} & \text { Calcium } \\ \mathrm{CEC} & \text { Cation Exchange Capacity } \\ \mathrm{CS} \text { rotation } & \text { Corn-soybean rotation system }\end{array}$




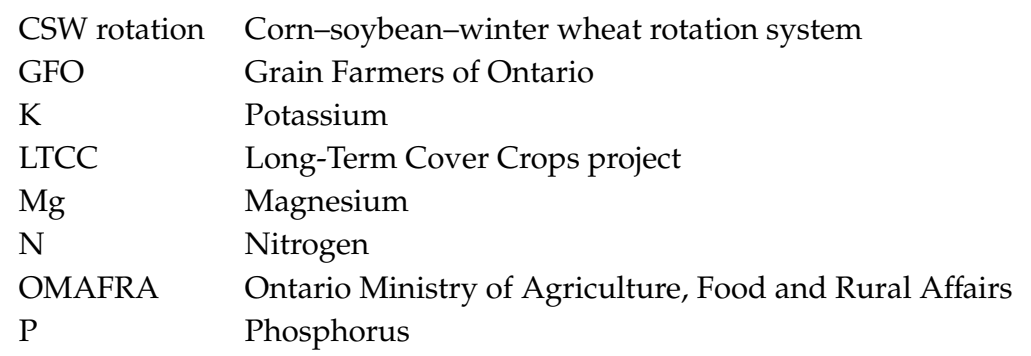

\section{References}

1. Sustainable Agriculture Network-SAN. Managing Cover Crops Profitably, 3rd ed.; Sustainable Agriculture Network: Beltsville, MD, USA, 2008.

2. Soil Science Society of America (SSSA). Internet Glossary of Soil Science. Available online: http://www.soils. org/sssagloss (accessed on 14 December 2018).

3. Jarecki, M.K.; Lal, R. Crop management for soil carbon sequestration. Crit. Rev. Plant Sci. 2003, 22, 471-502. [CrossRef]

4. Franzluebbers, A.J.; Hons, F.M.; Zuberer, D.A. Long-term changes in soil carbon and nitrogen pools in wheat management system. Soil Sci. Soc. Am. J. 1994, 58, 1639-1645. [CrossRef]

5. Bowman, G.; Shirley, C.; Cramer, C. Managing Cover Crops Profitably, 2nd ed.; USDA Sustainable Agriculture Network: Beltsville, MD, USA, 2000.

6. Follett, R.F. Soil management concepts and carbon sequestration in cropland soils. Soil Tillage Res. 2001, 61, 77-92. [CrossRef]

7. Wilson, G.F.; Lal, R.; Okigbo, B.N. Effects of cover crops on soil structure and on yield subsequent arable crops grown under strip tillage on an eroded alfisol. Soil Tillage Res. 1982, 2, 233-250. [CrossRef]

8. Hermawan, B.; Bomke, A.A. Effects of winter cover crops and successive spring tillage on soil aggregation. Soil Tillage Res. 1997, 44, 109-120. [CrossRef]

9. Dabney, S.M.; Delgado, J.A.; Reeves, D.W. Using winter cover crops to improve soil and water quality. Commun. Soil Sci. Plant Anal. 2001, 32, 1221-1250. [CrossRef]

10. Williams, S.M.; Weil, R.R. Crop cover root channels may alleviate soil compaction effects on Soybean crop. Soil Sci. Soc. Am. J. 2004, 68, 1403-1409. [CrossRef]

11. Lal, R.; Reginer, E.; Eckert, D.J.; Edwards, W.M.; Hammond, R. Expectation for cover crops for sustainable agriculture. In Cover Crops for Clean Water; Hargrove, W.L., Ed.; Soil Water Conservation Society: Ankeny, IA, USA, 1991; pp. 1-11.

12. Ingles, A.C.; Van Horn, M.; Miller, P.R. Selecting the right cover crops gives multiple benefits. Calif. Agric. 1994, 48, 43-48. [CrossRef]

13. Couëdel, A.; Alletto, L.; Kirkegaard, J.; Justes, É. Crucifer glucosinolate production in legume-crucifer cover crop mixtures. Eur. J. Agron. 2018, 96, 22-33. [CrossRef]

14. Sainju, U.M.; Singh, B.P.; Whitehead, W.F. Cover crops and nitrogen fertilization effects on soil carbon and nitrogen and tomato yield. Can. J. Soil Sci. 2000, 80, 523-532. [CrossRef]

15. Kuo, S.; Sainju, M.U.; Jellum, E. Winter cover crop effects on soil organic carbon and carbohydrate in soil. Soil Sci. Soc. Am. J. 1997, 61, 145-152. [CrossRef]

16. Kuo, S.; Sainju, M.U.; Jellum, E. Winter cover cropping influence on nitrogen in soil. Soil Sci. Soc. Am. J. 1997, 61, 1392-1399. [CrossRef]

17. Lal, R.; Bruce, J.P. The potential of world cropland soils to sequester carbon and mitigate the greenhouse effect. Environ. Sci. Policy 1999, 2, 177-185. [CrossRef]

18. Gaudin, A.C.M.; Westra, S.; Loucks, C.E.S.; Janovicek, K.; Martin, R.C.; Deen, W. Improving resilience of Northern field crop systems using inter-seeded red clover: A review. Agronomy 2013, 3, 148-180. [CrossRef]

19. Wyngaarden, S.L.; Gaudin, A.C.; Deen, W.; Martin, R.C. Expanding red clover (Trifolium pratense) usage in the corn-soy-wheat rotation. Sustainability 2015, 7, 15487-15509. [CrossRef]

20. Finney, D.M.; Murrell, E.G.; White, C.M.; Baraibar, B.; Barbercheck, M.E.; Bradley, B.A.; Cornelisse, S.; Hunter, M.C.; Kaye, J.P.; Mortensen, D.A.; et al. Ecosystem services and disservices are bundled in simple and diverse cover cropping systems. Agric. Environ. Lett. 2017, 2, 170033. [CrossRef] 
21. Gaudin, A.C.M.; Janovicek, K.; Martin, R.C.; Deen, W. Approaches to optimizing nitrogen fertilization in a winter wheat-red clover (Trifolium pretense L.) relay cropping system. Field Crop. Res. 2014, 155, 192-201. [CrossRef]

22. Stewart, M. Nitrogen Fertilizer Cover Crop Responses Seeded after Wheat and Effect on Grain Corn Yield; Thesis submitted to University of Guelph: Guelph, ON, Canada, 2019.

23. Weil, R.; Kremen, A. Thinking across and beyond disciplines to make cover crops pay. J. Sci. Food Agust. 2007, 87, 551-557. [CrossRef]

24. Snapp, S.S.; Swinton, S.M.; Labarta, R.; Mutch, D.; Black, J.R.; Leep, R.; Nyiraneza, J.; O’Neil, K. Evaluating cover crops for benefits, costs and performance within cropping system niches. Agron. J. 2005, 97, 322-332. [CrossRef]

25. Chu, M.; Jagadamma, S.; Walker, F.R.; Eash, N.S.; Buschermohle, M.J.; Duncan, L.A. Effect of multispecies cover crop mixture on soil properties and crop yield. Agric. Environ. Lett. 2017, 2, 170030. [CrossRef]

26. PSE-Penn State Exension. Making the Most of Mixtures: Considerations for Winter Cover Crops in Temperate Climates. Available online: https://extension.psu.edu/making-the-most-of-mixturesconsiderations-for-winter-cover-crops (accessed on 28 January 2020).

27. Coombs, C.; Lauzon, J.D.; Deen, B.; Van Eerd, L.L. Legume cover crop management on nitrogen dynamics and yield in grain corn systems. Field Crop. Res. 2017, 201, 75-85. [CrossRef]

28. Chen, G.; Weil, R.R. Penetration of cover crop roots through compacted soils. Plant Soil. 2010, 331, 31-43. [CrossRef]

29. Kramberger, B.; Gselman, A.; Kristl, J.; Lešnik, M.; Šuštar, V.; Muršec, M.; Podvršnik, M. Winter cover crop: The effects of grass-clover mixture proportion and biomass management on maize and the apparent residual $\mathrm{N}$ in the soil. Eur. J. Agron. 2014, 55, 63-71. [CrossRef]

30. Tosti, G.; Benincasa, P.; Farneselli, M.; Tei, F.; Guiducci, M. Barley-hairy vetch mixture as cover crop for green manuring and the mitigation of $\mathrm{N}$ leaching risk. Eur. J. Agron. 2014, 54, 34-39. [CrossRef]

31. NRCS-USDA-Natural Resources Conservation Service, United States Department of Agriculture. Planting Specification Guide: Cover Crop. Available online: https:/www.nrcs.usda.gov/Internet/FSE_DOCUMENTS/ stelprdb1081555.pdf (accessed on 21 January 2020).

32. Isleib, J. Single Species Versus Multiple Species Cover Crops. Available online: https://www.canr.msu.edu/ news/single_species_versus_multiple_species_cover_crops (accessed on 28 December 2018).

33. Couëdel, A.; Alletto, L.; Justes, É. Crucifer-legume cover crop mixtures provide effective sulphate catch crop and sulphur green manure services. Plant Soil 2018, 1-16. [CrossRef]

34. Couëdel, A.; Alletto, L.; Tribouillois, H.; Justes, É. Cover crop crucifer-legume mixtures provide effective nitrate catch crop and nitrogen green manure ecosystem services. Agric. Ecosys. Environ. 2018, 254, 50-59. [CrossRef]

35. Mallinger, R.E.; Franco, J.G.; Prischmann-Voldseth, D.A.; Prasifka, J.R. Annual cover crops for managed and wild bees: Optimal plant mixtures depend on pollinator enhancement goals. Agr. Ecosyst. Environ. 2018, 273, 107-116. [CrossRef]

36. Wortman, S.E.; Francis, C.A.; Bernards, M.L.; Drijber, R.A.; Lindquist, J.L. Optimizing cover crop benefits with diverse mixtures and an alternative termination method. Agron. J. 2012, 104, 1425-1435. [CrossRef]

37. Smith, R.G.; Atwood, L.W.; Warren, N.D. Increased productivity of a cover crop mixture is not associated with enhanced agroecosystem services. PLoS ONE 2014, 9, e97351. [CrossRef]

38. Finney, D.M.; White, C.M.; Kaye, J.P. Biomass production and carbon/nitrogen ratio influence ecosystem services from cover crop mixtures. Agron. J. 2016, 108, 39-52. [CrossRef]

39. McGuire, A. Cover Crop Monoculture vs Mixture Update. Available online: https://csanr.wsu.edu/2018cover-crop-update/ (accessed on 28 December 2018).

40. Sanderson, M.; Johnson, H.; Hendrickson, J. Cover crop mixtures grown for annual forage in a semi-arid environment. Agron. J. 2018, 110, 525-534. [CrossRef]

41. Eberle, C.A.; Thom, M.D.; Nemec, K.T.; Forcella, F.; Lundgren, J.G.; Gesch, R.W.; Riedell, W.E.; Papiernik, S.K.; Wagner, A.; Peterson, D.H.; et al. Using pennycress, camelina, and canola cash cover crops to provision pollinators. Ind. Crop. Prod. 2015, 75, 20-25. [CrossRef]

42. Franzluebbers, A.J.; Stuedemann, J.A. Does grazing of cover crops impact biologically active soil carbon and nitrogen fractions under inversion or no tillage management? J. Soil Water Conserv. 2015, 70, 365-373. [CrossRef] 
43. SARE-Sustainable Agriculture Research \& Education. Types of Cover crops. Available online: https://www.sare.org/Learning-Center/Books/Building-Soils-for-Better-Crops-3rd-Edition/TextVersion/Cover-Crops/Types-of-Cover-Crops (accessed on 14 January 2020).

44. Johnson, G.A.; Kantar, M.B.; Betts, K.J.; Wyse, D.L. Field pennycress production and weed control in a double crop system with soybean in Minnesota. Agron. J. 2015, 107, 532-540. [CrossRef]

45. Johnson, G.A.; Wells, M.S.; Anderson, K.; Gesch, R.W.; Forcella, F.; Wyse, D.L. Yield tradeoffs and nitrogen between pennycress, camelina, and soybean in relay- and double-crop systems. Agron. J. 2017, 109, 2128-2135. [CrossRef]

46. OMAFRA-Ontario Ministry of Agriculture, Food and Rural Affairs. Winter Cover Crops. Available online: https://omafra.gov.on.ca/english/environment/bmp (accessed on 10 January 2020).

47. Noland, R.L.; Wells, M.S.; Sheaffer, C.C.; Baker, J.M.; Martison, K.L.; Coulter, J.A. Establishment and function of cover crops interseeded into corn. Crop Sci. 2018, 58, 1-11. [CrossRef]

48. Al-Kaisi, M.M.; Archontoulis, S.V.; Kwaw-Mensah, D.; Miguez, F. Tillage and crop rotation effects on corn agronomic response and economic returns at seven Iowa locations. Agron. J. 2015, 107, 1411-1424. [CrossRef]

49. Chapagain, T. Farming in Northern Ontario: Untapped potential for the future. Agron 2017, 7, 59. [CrossRef]

50. Reeves, D.W. Cover crops and rotations. In Crops Residue Management; Hatfield, J.L., Steward, B.A., Eds.; CRC Press. Inc.: Boca Raton, FL, USA, 1994; pp. 125-171.

51. Ekstrom, D. Winter Cover Crops Become Weeds? Available online: https://www.agriculture.com/crops/ cover-crops/winter-cover-crops-become-weeds_568-ar42575 (accessed on 28 January 2020).

52. ISU-Iowa State University. Terminating Cover crops: What's Your Plan? Available online: https: //crops.extension.iastate.edu/cropnews/2016/03/terminating-cover-crops-whats-your-plan (accessed on 10 January 2020).

53. Creamer, N.G.; Bennet, M.A.; Stinner, B.R. Evaluation of cover crop mixtures for use in vegetable production systems. Hort. Sci. 1997, 32, 866-870. [CrossRef]

54. Cooper, C.S. Growth of the legume seedling. Adv. Agron. 1977, 29, 119-139.

55. Turmel, M.S.; Entz, M.H.; Tenuta, M.; May, W.E.; LaFond, G.P. The influence of a long-term black medic (Medicago lupulina cv George) cover crop on arbuscular mycorrhizal fungal colonization and nutrient uptake in flax (Linum usitgatissimum) under zero-tillage management. Can. J. Plant Sci. 2011, 91, 1071-1076. [CrossRef]

56. GRDC - Grains Research and Development Corporation. Oats. Available online: Grdc.com.au\T1 guilsinglrightassets\T1 \guilsinglrightpdf_file\T1\guilsinglrightgrdc-grownotes-oats-northern.pdf (accessed on 16 January 2020).

57. Thelen, K.D.; Leep, R. Integrating a double-cropped winter annual forage into a corn-soybean rotation. Crop Manag. 2002, 1. [CrossRef]

58. Wallace, J.M.; Williams, A.; Liebert, J.A.; Ackroyd, V.J.; Vann, R.A.; Curran, W.S.; Keene, C.L.; VanGessel, M.J.; Ryan, M.R.; Mirsky, S.B. Cover crop-based, organic rotational no-till corn and soybean production systems in the Mid-Atlantic United States. Agriculture 2017, 7, 34. [CrossRef]

59. Jolliffe, P.A.; Wanjau, F.M. Competition and productivity in crop mixtures: Some properties of productive intercrops. J. Agric. Sci. 1999, 132, 425-435. [CrossRef]

60. Jolliffe, P.A. The replacement series. J. Ecol. 2000, 88, 371-385. [CrossRef]

(C) 2020 by the authors. Licensee MDPI, Basel, Switzerland. This article is an open access article distributed under the terms and conditions of the Creative Commons Attribution (CC BY) license (http://creativecommons.org/licenses/by/4.0/). 